\title{
Physicochemical Characteristics of Selected Sachet and Bottled Water in Abraka, Delta State
}

\author{
Otobrise C., ${ }^{1, *}$ Azuh T. C., ${ }^{2}$ Mmakwe E. I., ${ }^{3}$ Ogbakpa E. ${ }^{4}$ and Tolorun C. O. ${ }^{5}$ \\ ${ }^{1,2,3,4,5}$ Department of Chemistry, Faculty of Science, Delta State University, Abraka, Delta State, Nigeria \\ Corresponding Author: *otobrisec@delsu.edu.ng
}

https://doi.org/10.36263/nijest.2021.01.0248

\begin{abstract}
Some physicochemical properties of five brands of sachet and five brands of bottled water sold/produced in Abraka; Ethiope East Local Government Area of Delta State was investigated. Amounts of heavy in the water samples were also determined. The results were compared with World Health Organization (WHO) standards and Nigerian Standard for Drinking Water Quality (NSDWQ) respectively. Seventy percent of the samples had $\mathrm{pH}$ levels below the minimum level of 6.50 recommended by $W H O$ and NSDWQ, suggesting that the water samples are acidic. The slight acidity of the water samples may not be unconnected to impurities from poor treatment techniques. Results for other physicochemical parameters: EC (78.60 $\pm 34.06 \mu \mathrm{s} / \mathrm{cm})$, TDS $(42.80 \pm$ $18.46 \mathrm{mg} / \mathrm{l})$, Temperature $\left(30.02 \pm 0.46^{\circ} \mathrm{C}\right), \mathrm{Cl}(16.88 \pm 7.01 \mathrm{mg} / \mathrm{l}), \mathrm{NO}_{3}^{-}(0.12 \pm 0.05 \mathrm{mg} / \mathrm{l}), \mathrm{NO}_{2}^{-}$ $(<0.001 \mathrm{mg} / \mathrm{l}), \mathrm{TH}(10.60 \pm 7.09 \mathrm{mg} / \mathrm{l}), \mathrm{Cu}(0.05 \pm 0.00 \mathrm{mg} / \mathrm{l}), \mathrm{Fe}(0.34 \pm 0.19 \mathrm{mg} / \mathrm{l}), \mathrm{Zn}(0.11 \pm$ $0.02 \mathrm{mg} / \mathrm{l})$ and $\mathrm{Mn}(0.03 \pm 0.00 \mathrm{mg} / \mathrm{l})$ for sachet water samples; EC $(99.60 \pm 76.18 \mu \mathrm{s} / \mathrm{cm}), T D S$ $(54.20 \pm 41.84 \mathrm{mg} / \mathrm{l})$, Temperature $\left(29.96 \pm 0.21{ }^{\circ} \mathrm{C}\right), \mathrm{Cl}^{-}(20.85 \pm 17.44 \mathrm{mg} / \mathrm{l}), \mathrm{NO}_{3}^{-}(0.12 \pm$ $0.03 \mathrm{mg} / \mathrm{l}), \mathrm{NO}_{2}^{-}(0.01 \pm 0.01 \mathrm{mg} / \mathrm{l}), \mathrm{TH}(15.00 \pm 16.36 \mathrm{mg} / \mathrm{l}), \mathrm{Cu}(0.04 \pm 0.01 \mathrm{mg} / \mathrm{l}), \mathrm{Fe}(0.20 \pm$ $0.15 \mathrm{mg} / \mathrm{l}), \mathrm{Zn}(0.11 \pm 0.03 \mathrm{mg} / \mathrm{l})$ and $\mathrm{Mn}(0.09 \pm 0.01 \mathrm{mg} / \mathrm{l})$ for bottled water samples; were within permissible limits, indicating that the water samples are good enough for human consumption.
\end{abstract}

Keywords: Sachet water, Bottled water, Physicochemical characteristics, Potable, Abraka

\subsection{Introduction}

Water is very crucial for the sustenance of lives (Gangil et al., 2013; Thliza et al., 2015). Virtually all processes of life in the atmosphere, lithosphere or hydrosphere require water (Aroh et al., 2013). Water is an essential part of human diet and is required for maintaining personal hygiene, for drinking, domestic, industrial and agricultural uses (Isikwue and Chikezie, 2014; Thliza et al., 2015). In many developing countries, availability of potable water is a perennial challenge and has become a matter of concern to families and communities (Maduka et al., 2014). Studies have shown a gross inadequacy of access to potable water amongst the world's population (Akinde et al., 2011; Oyelude and Ahenkorah, 2011).

In Nigeria, the situation is worrisome. Several studies have corroborated the inadequacy of the country's potable water supply. (Gbadegesin and Olorunfemi, 2007; Aderibigbe et al., 2008; Maconachie, 2008; Adamu, 2009; Omalu et al., 2011).This has occasioned an increase in water related illnesses that has continued to be one of the foremost health burdens worldwide (Onifade and Ilori, 2008; Omalu et al., 2011). According to Akunyili (2003), the Government's persistent inability to provide the required quality and quantity of water for the growing population contributed in no small measure to the proliferation of the so-called 'pure water' companies in Nigeria. The proliferation of sachet and bottled drinking water products brings to fore the argument as to whether they are hygienically produced, especially when the poor sanitary conditions in most urban and rural areas of Nigeria coupled with irregular and insufficient monitoring of sachet and bottled water producers by regulating agencies is taken into cognizance (Adekunle et al., 2004).

Akpoborie and Ehwarimo (2012) analyzed a variety of common packaged water products in Warri. The potability of the water samples was determined by investigating coliform count, selected physical 
and chemical properties as well as presence of heavy metals like cadmium, chromium and lead. Sachet and bottled water samples were procured from street vendors, wholesale shops and production plants. The results showed that $\mathrm{pH}$ ranged from 7.1 to 8.2; Total dissolved solids (TDS) was between 2.26 to $89.6 \mathrm{mg} / \mathrm{l}$; Turbidity: 0.45 to $2.55 \mathrm{NTU}$; Calcium: 0.11 to $1.21 \mathrm{mg} / \mathrm{l}$; Magnesium: 0.03 to $0.31 \mathrm{mg} / \mathrm{l}$; Sulphate: 0 to $1.21 \mathrm{mg} / \mathrm{l}$; chloride: 0.5 to $3.1 \mathrm{mg} / \mathrm{l}$; nitrate: 0.2 to $0.25 \mathrm{mg} / \mathrm{l}$. The cadmium level in three brands of the water samples ranged from 0.001 to $0.002 \mathrm{mg} / \mathrm{l}$. Lead concentrations ranged from 0.001 to $0.003 \mathrm{mg} / \mathrm{l}$ and chromium levels ranged from 0.001 to $0.002 \mathrm{mg} / \mathrm{l}$. The parameters analysed were well below regulatory guidelines. However, the authors observed a significantly small amount of TDS in the water samples.

An investigation into the potability of sachet water available to residents of Kano metropolitan area was carried out by Ezeugwunne et al. (2009). The concentrations of metals ( $\mathrm{Zn}, \mathrm{Pb}, \mathrm{Fe}$, and $\mathrm{Cu}$ ), conductivity, dissolved solids and hardness were within the World Health Organization's (WHO) permissible limits. However, some of the $\mathrm{pH}$ values were above the WHO permissible limits. Adekunle et al. (2004) assessed the socio-economic and health implications sachet water in Ibadan Nigeria. The authors reported that the physical parameters were within the WHO limits for drinking water quality, except for $\mathrm{pH}$. Some chemical properties studied were also within the WHO limits. However, aluminum, fluoride and cyanide concentrations in the water samples were not within the WHO limits.

Sachet and bottled water are regulated as food products in Nigeria by the National Agency for Food and Drug Administration and Control (NAFDAC). The agency relies on WHO and NSDWQ standards for the product regulation, registration and certification. Packaged water is relatively affordable and convenient to carry and has increasingly become popular. However, many local manufacturers of sachet and bottled water do not adhere strictly to NAFDAC guidelines. This undermines the safety of such water for human consumption. The need to investigate the quality of packaged water therefore becomes imperative. The objective of this study is to investigate the quality of packaged water produced or sold in Abraka town.

\subsection{Methodology}

\subsection{Description of study area}

Abraka is a sprawling University town situated between latitude $5^{\circ} 45^{\prime}$ and $5^{\circ} 50^{\prime} \mathrm{N}$ and longitude $6^{\circ}$ and $6^{\circ} 15^{\prime} \mathrm{E}$.It is unevenly lowland with a gradient that slopes gently towards the River Ethiope. It is a collection of a number of linear communities in Ethiope East Local Government Area of Delta State, Nigeria. It is majorly populated by students, civil servants, farmers and small scale business owners, because it hosts the three sites of the Abraka campus of the Delta State University and a large market respectively. 


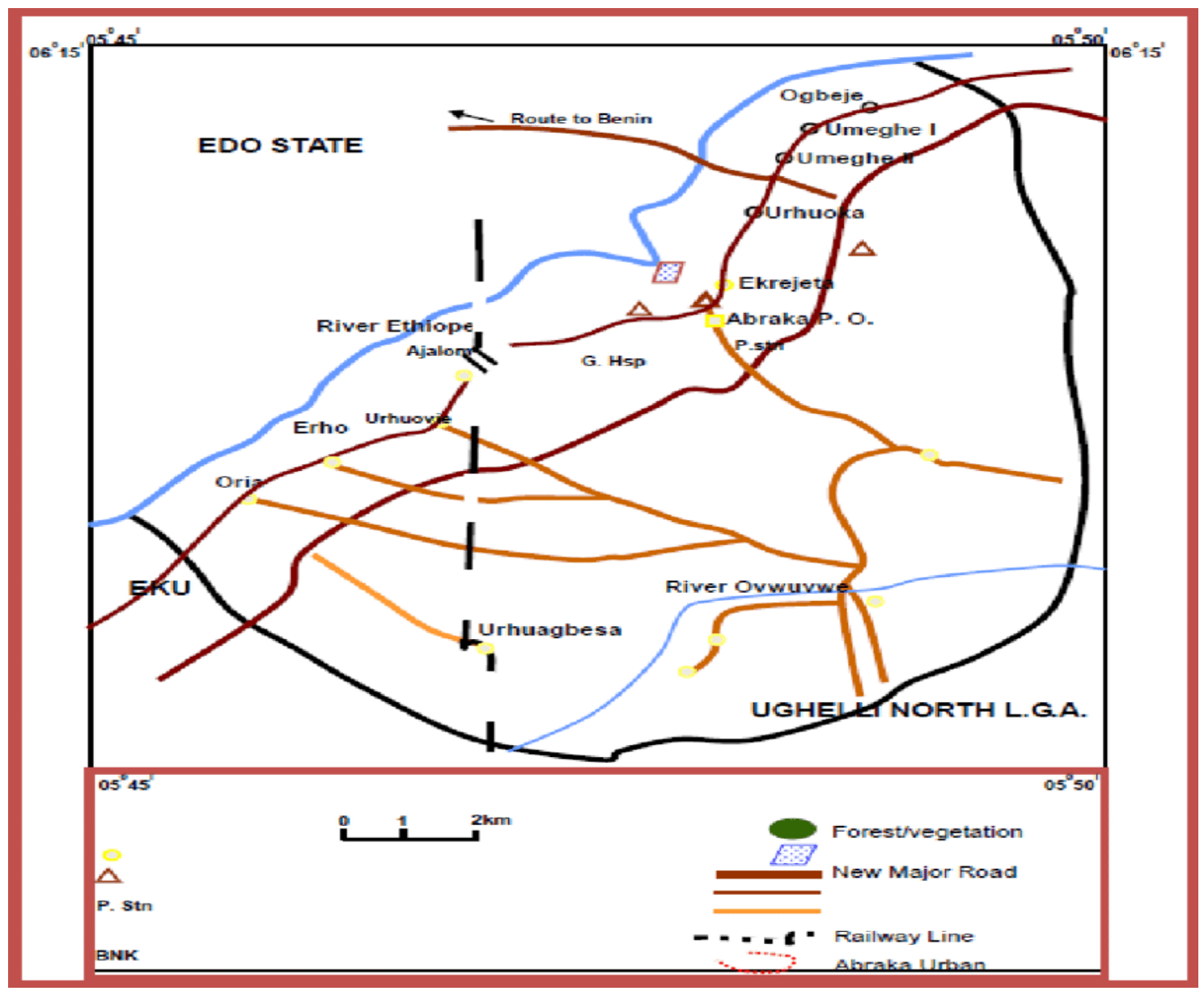

Figure 1: Map of Abraka showing its several linear settlements

Source:https://www.researchgate.net/figure/Map-of-Abraka-Ethiope-East-LGA-Delta-State-Nigeria

\subsection{Collection/preservation of samples}

Ten (10) different bottled and sachet water brands were procured at random on the $12^{\text {th }}$ of March, 2020 from the different communities that constitute Abraka town. Particular attention was on popular brand names commonly consumed in Abraka. Five (5) samples of each brand were purchased to obtain a composite sample of each satchet and bottled water brand. To protect the identity of each brand, they were labelled sample A to J. Samples A to E are sachet water, while F to J are bottled water samples. The samples were stored in the refrigerator at $4{ }^{\circ} \mathrm{C}$ prior analyses.

\subsection{Methods}

\subsection{1. $\mathrm{pH}$ and Temperature}

The $\mathrm{pH}$ of each water sample was determined with a $\mathrm{pH}$ meter as described in standard methods (APHA 4500- $\mathrm{H}^{+}$Electrometric, 2017). The temperature of each water sample was measured with a digital thermometer (APHA 2550B Electrometric, 2017). About 200ml of water sample was measured into a conical flask. The thermometer was lowered into the sample until the mercury bulb was sufficiently covered by the sample and the temperature was read and recorded.

\subsubsection{Conductivity and turbidity}

The conductivity of each sample was determined using digital conductivity meter (APHA 2510B Electrometric, 2017). The turbidity was determined by the nephelometric method with the aid of a laboratory nephelometer (APHA 2130B Nephelometric, 2017).

\subsubsection{Total Dissolved Solids}

Total Dissolved Solids (TDS) was determined with TDS meter. The electrode was rinsed with deionised water followed by the water sample. The rinsed electrode was allowed to stabilize in the 
sample for 1 minute after which the TDS value was read directly inmg/l (APHA 2540C Gravimetric, 2017).

\subsubsection{Colour}

Colour was determined by the method reported in the work of Dinrifo et al. (2010). A Lovibond visual colour comparator (APHA 2120B Visual) was used. Ten tubes of Lovibond visual colour comparator were filled with each water sample and the eleventh tube was filled with distilled water as standard control. The tubes were placed in the comparator and aligned by rotating the disc until a nearest colour match was observed. Total Hardness (TH) was determined by the EDTA titrimetric method using Eriochrome black $\mathrm{T}$ as indicator. The titration was done at $\mathrm{pH}=10$ (APHA 2340C Titrimetric, 2017).

\subsubsection{Chloride, nitrate and nitrite concentrations}

Chloride content was determined by Argentometric/Titrimetric method (APHA 4500-Cl-B Titrimetric, 2017). Nitrate $\left(\mathrm{NO}_{3}^{-}\right)$and nitrite $\left(\mathrm{NO}_{2}{ }^{-}\right)$contents were determined by colorimetric method using a potable UV-visible spectrophotometer (Searchtech Instrument, $752 \mathrm{~N}$ model, India) (APHA 4500 E Colorimetric, 2017) and (APHA 4500- $\mathrm{NO}_{2}$ Colorimetric, 2017) respectively.

\subsubsection{Heavy metals}

Heavy metals such as copper $(\mathrm{Cu})$, lead $(\mathrm{Pb})$, iron $(\mathrm{Fe})$, zinc $(\mathrm{Zn})$, manganese $(\mathrm{Mn})$ were determined by Flame Atomic Absorption Spectrophotometry (FAAS) using acetylene/air with Atomic Absorption Spectrophotometer, Varian Spetra AA 600 model (USA) (APHA 3111B FAAS, 2017). Arsenic (As) was determined using AAS-Hydride method (APHA 3111B AAS-Hydride, 2017).

\subsubsection{Statistical analysis}

Data analysis was done by independent samples t-test using Statistical Package for Social Sciences (SPSS) version 20 Software. At a significant level ( $\mathrm{p}$ - value) of 0.05 ; differences between the means of the two sets of data for each parameter were considered not significant at $\mathrm{p}>0.05$.

\subsection{Results and Discussion}

Tables 1 and 2 show the physical and chemical properties of the sachet and bottled water samples determined in this study. A comparison of the average values of physicochemical parameters and heavy metals concentration of the water samples with international and national guidelines for drinking water is presented on Table 3. Samples A to E are sachet water samples while samples F to J are bottled water samples.

The $\mathrm{pH}$ values of the sachet water samples ranged from $4.11-6.65$, while that of the bottled water ranged from $5.17-7.77$. There is a significant deviation in the $\mathrm{pH}$ values of most of the water samples from acceptable standards as can be observed in Figure 1. Only samples E, F and I had values within the acceptable limit. The $\mathrm{pH}$ values of the other water samples were below acceptable limits. This is similar to the observations of Oyelude and Ahenkorah (2012). At a degree of freedom (df) equal to 8 and a $\mathrm{p}$-value of 0.116 , there was no significant difference between the $\mathrm{pH}$ values obtained for the sachet and bottled water samples. The $\mathrm{pH}$ of water affects transformation processes of the various forms of nutrients and metals. Extreme $\mathrm{pH}$ values poses health risks to humans. 
Table1: Physicochemical properties of the sachet water samples

\begin{tabular}{|l|c|c|c|c|c|}
\hline \multirow{2}{*}{ Parameter } & \multicolumn{5}{|c|}{ Sachet water samples } \\
\cline { 2 - 6 } & A & B & C & D & E \\
\hline pH @ 25 $\left({ }^{\circ} \mathrm{C}\right)$ & 6.40 & 4.57 & 4.50 & 4.11 & 6.65 \\
\hline $\mathrm{EC}(\mu \mathrm{s} / \mathrm{cm})$ & 20 & 88 & 91 & 109 & 85 \\
\hline TDS $(\mathrm{mg} / \mathrm{l})$ & 11 & 48 & 50 & 59 & 46 \\
\hline Turbidity $(\mathrm{NTU})$ & $<0.1$ & $<0.1$ & $<0.1$ & $<0.1$ & $<0.1$ \\
\hline Temp. $\left({ }^{\circ} \mathrm{C}\right)$ & 30.10 & 30.20 & 29.80 & 29.90 & 30.10 \\
\hline Colour $(\mathrm{Pt}-\mathrm{Co})$ & $<1$ & $<1$ & $<1$ & $<1$ & $<1$ \\
\hline $\mathrm{Cl}^{-}(\mathrm{mg} / \mathrm{l})$ & 6.00 & 17.90 & 20.24 & 24.85 & 15.39 \\
\hline $\mathrm{NO}_{3}^{-}(\mathrm{mg} / \mathrm{l})$ & 0.10 & 0.09 & 0.07 & 0.21 & 0.12 \\
\hline $\mathrm{NO}_{2}^{-}(\mathrm{mg} / \mathrm{l})$ & $<0.001$ & $<0.001$ & $<0.001$ & $<0.001$ & 0.080 \\
\hline $\mathrm{TH}(\mathrm{mg} / \mathrm{l})$ & 6.00 & 7.00 & 10.00 & 7.00 & 23.00 \\
\hline $\mathrm{Cu}(\mathrm{mg} / \mathrm{l})$ & 0.05 & $\mathrm{ND}$ & $\mathrm{ND}$ & $\mathrm{ND}$ & $\mathrm{ND}$ \\
\hline $\mathrm{Pb}(\mathrm{mg} / \mathrm{l})$ & $\mathrm{ND}$ & $\mathrm{ND}$ & $\mathrm{ND}$ & $\mathrm{ND}$ & $\mathrm{ND}$ \\
\hline $\mathrm{Fe}(\mathrm{mg} / \mathrm{l})$ & 0.20 & $\mathrm{ND}$ & $\mathrm{ND}$ & $\mathrm{ND}$ & 0.47 \\
\hline $\mathrm{Zn}(\mathrm{mg} / \mathrm{l})$ & 0.09 & 0.12 & 0.14 & 0.11 & 0.09 \\
\hline $\mathrm{Mn}(\mathrm{mg} / \mathrm{l})$ & $\mathrm{ND}$ & ND & ND & ND & 0.03 \\
\hline $\mathrm{As}(\mathrm{mg} / \mathrm{l})$ & $\mathrm{ND}$ & $\mathrm{ND}$ & $\mathrm{ND}$ & $\mathrm{ND}$ & $\mathrm{ND}$ \\
\hline
\end{tabular}

Table2: Physicochemical properties of the bottled water samples

\begin{tabular}{|l|c|c|c|c|c|}
\hline \multirow{2}{*}{ Parameter } & \multicolumn{5}{|c|}{ Bottled water samples } \\
\cline { 2 - 6 } & $\mathrm{F}$ & $\mathrm{G}$ & $\mathrm{H}$ & $\mathrm{I}$ & $\mathrm{J}$ \\
\hline $\mathrm{pH}$ @ 25 $\left({ }^{\circ} \mathrm{C}\right)$ & 7.21 & 5.17 & 5.93 & 7.77 & 6.33 \\
\hline $\mathrm{EC}(\mu \mathrm{s} / \mathrm{cm})$ & 142 & 36 & 83 & 209 & 28 \\
\hline TDS $(\mathrm{mg} / \mathrm{l})$ & 78 & 19 & 45 & 114 & 15 \\
\hline Turbidity $(\mathrm{NTU})$ & $<0.1$ & $<0.1$ & $<0.1$ & $<0.1$ & $<0.1$ \\
\hline Temp. $\left({ }^{\circ} \mathrm{C}\right)$ & 30.10 & 29.70 & 29.80 & 30.20 & 30.00 \\
\hline $\mathrm{Colour}(\mathrm{Pt}-\mathrm{Co})$ & $<1$ & $<1$ & $<1$ & $<1$ & $<1$ \\
\hline $\mathrm{Cl}^{-}(\mathrm{mg} / \mathrm{l})$ & 28.04 & 8.10 & 14.12 & 47.99 & 6.00 \\
\hline $\mathrm{NO}_{3}{ }^{-}(\mathrm{mg} / \mathrm{l})$ & 0.14 & 0.15 & 0.09 & 0.15 & 0.08 \\
\hline $\mathrm{NO}_{2}{ }^{-}(\mathrm{mg} / \mathrm{l})$ & $<0.001$ & $<0.001$ & 0.009 & 0.018 & $<0.001$ \\
\hline $\mathrm{TH}(\mathrm{mg} / \mathrm{l})$ & 44.00 & 5.00 & 8.00 & 11.0 & 7.0 \\
\hline $\mathrm{Cu}(\mathrm{mg} / \mathrm{l})$ & 0.05 & $\mathrm{ND}$ & 0.03 & $\mathrm{ND}$ & $\mathrm{ND}$ \\
\hline $\mathrm{Pb}(\mathrm{mg} / \mathrm{l})$ & $\mathrm{ND}$ & $\mathrm{ND}$ & $\mathrm{ND}$ & $\mathrm{ND}$ & $\mathrm{ND}$ \\
\hline $\mathrm{Fe}(\mathrm{mg} / \mathrm{l})$ & 0.01 & $\mathrm{ND}$ & 0.24 & 0.37 & 0.18 \\
\hline $\mathrm{Zn}(\mathrm{mg} / \mathrm{l})$ & 0.09 & 0.11 & 0.15 & 0.06 & 0.13 \\
\hline $\mathrm{Mn}(\mathrm{mg} / \mathrm{l})$ & $\mathrm{ND}$ & $\mathrm{ND}$ & 0.10 & 0.08 & $\mathrm{ND}$ \\
\hline $\mathrm{As}(\mathrm{mg} / \mathrm{l})$ & $\mathrm{ND}$ & $\mathrm{ND}$ & $\mathrm{ND}$ & $\mathrm{ND}$ & $\mathrm{ND}$ \\
\hline
\end{tabular}

Table3: Comparison of physicochemical properties of the water samples with National and International Guidelines

\begin{tabular}{|l|c|c|c|c|}
\hline Parameter & $\begin{array}{c}\text { Sachet Water } \\
\text { Mean } \pm \text { SD }\end{array}$ & $\begin{array}{c}\text { Bottled Water } \\
\text { Mean } \pm \text { SD }\end{array}$ & WHO & NSDWQ \\
\hline $\mathrm{pH} @ 25\left({ }^{\circ} \mathrm{C}\right)$ & $5.25 \pm 1.18$ & $6.48 \pm 1.03$ & $6.50-8.50$ & $6.50-8.50$ \\
\hline $\mathrm{EC}(\mu \mathrm{s} / \mathrm{cm})$ & $78.60 \pm 34.06$ & $99.60 \pm 76.18$ & NG & 1000.00 \\
\hline TDS $(\mathrm{mg} / \mathrm{l})$ & $42.80 \pm 18.46$ & $54.20 \pm 41.84$ & 1000.00 & 500.00 \\
\hline Turbidity $(\mathrm{NTU})$ & $<0.1$ & $<0.1$ & 0.2 & 5 \\
\hline Temp. $\left({ }^{\circ} \mathrm{C}\right)$ & $30.02 \pm 0.46$ & $29.96 \pm 0.21$ & Ambient & Ambient \\
\hline $\mathrm{Colour}(\mathrm{Pt}-\mathrm{Co})$ & $<1$ & $<1$ & 15 & 15 \\
\hline $\mathrm{Cl}^{-}(\mathrm{mg} / \mathrm{l})$ & $16.88 \pm 7.01$ & $20.85 \pm 17.44$ & 250.00 & 250.00 \\
\hline $\mathrm{NO}_{3}^{-}(\mathrm{mg} / \mathrm{l})$ & $0.12 \pm 0.05$ & $0.12 \pm 0.03$ & 50.00 & 50.00 \\
\hline $\mathrm{NO}_{2}{ }^{-}(\mathrm{mg} / \mathrm{l})$ & $<0.001$ & $0.01 \pm 0.01$ & 3.00 & 0.20 \\
\hline $\mathrm{TH}(\mathrm{mg} / \mathrm{l})$ & $10.60 \pm 7.09$ & $15.00 \pm 16.36$ & 500.00 & 150.00 \\
\hline $\mathrm{Cu}(\mathrm{mg} / \mathrm{l})$ & $0.05 \pm 0.00$ & $0.04 \pm 0.01$ & 2.00 & 1.00 \\
\hline $\mathrm{Pb}(\mathrm{mg} / \mathrm{l})$ & $\mathrm{ND}$ & $\mathrm{ND}$ & 0.01 & 0.01 \\
\hline $\mathrm{Fe}(\mathrm{mg} / \mathrm{l})$ & $0.34 \pm 0.19$ & $0.20 \pm 0.15$ & 1.00 & 0.30 \\
\hline $\mathrm{Zn}(\mathrm{mg} / \mathrm{l})$ & $0.11 \pm 0.02$ & $0.11 \pm 0.03$ & 5.00 & 3.00 \\
\hline $\mathrm{Mn}(\mathrm{mg} / \mathrm{l})$ & $0.03 \pm 0.00$ & $0.09 \pm 0.01$ & 0.40 & 0.20 \\
\hline $\mathrm{As}(\mathrm{mg} / \mathrm{l})$ & $\mathrm{ND}$ & $\mathrm{ND}$ & 0.01 & 0.01 \\
\hline
\end{tabular}

$W H O=$ World Health Organization (2017), Guideline for drinking water quality, 4th edition $N S D W Q=$ Nigerian Standard for Drinking Water Quality

$N G=$ No Guideline

$N D=$ Not Detected 


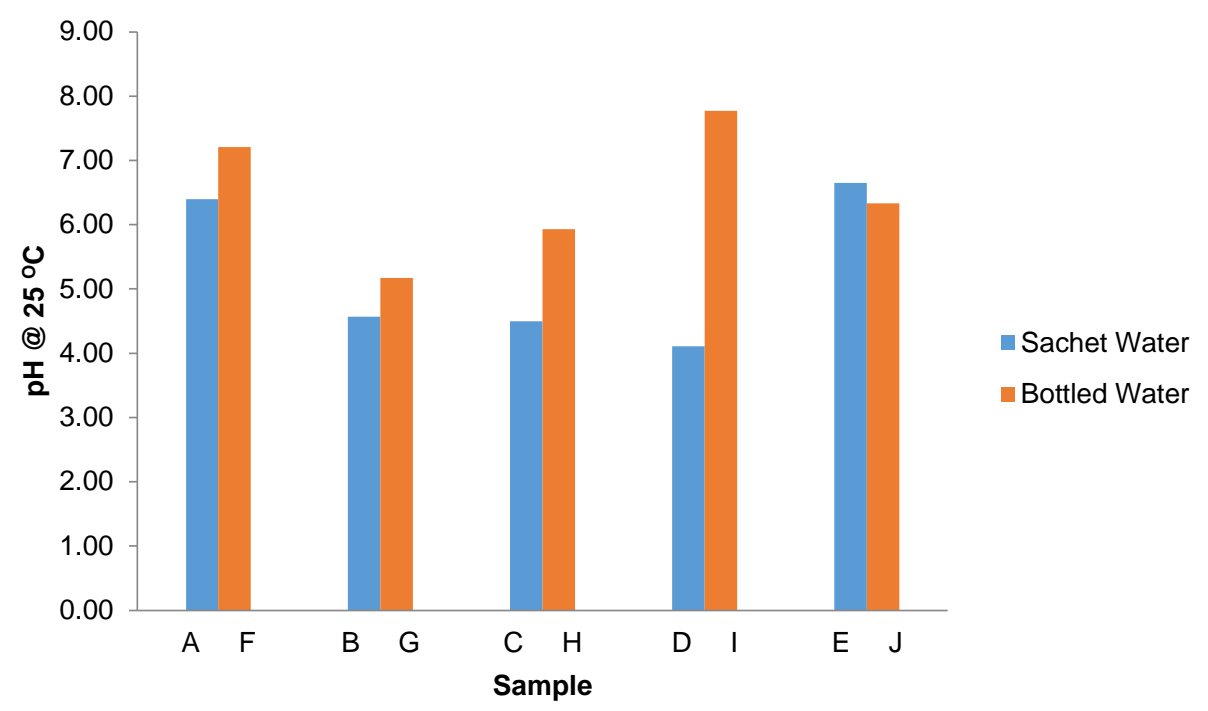

Figure 1: pH of Water Samples

Electrical conductivity (EC) of the sachet water samples ranged from 20.00 to $109.00 \mu \mathrm{scm}^{-1}$; while that of bottled water samples ranged from 28.00 to $209.00 \mu \mathrm{scm}^{-1}$. At a df of 8 and a p-value of 0.589 , there was no significant difference between the EC values obtained for the sachet and bottled water samples. The EC values were far below the maximum of $1000 \mu \mathrm{scm}^{-1}$ recommended for drinking water by NSDWQ. According to Nwidu et al. (2008) low EC values indicate the presence of minimal amount of dissolved salts (mineral elements such as calcium, magnesium and fluoride) in water. The long term drinking of packaged water with EC value that is lower than $40 \mu \mathrm{scm}^{-1}$ constitute a number of health risks such as higher probability of fracture in children, pregnancy disorder (preeclampsia), diuresis, premature or low baby weight at birth and increased tooth decay (Guler and Alpalsan, 2009).

TDS of the bottled water samples ranged from $15.0-114.0 \mathrm{mg} / \mathrm{l}$; that of the sachet water samples was $11.0-59.0 \mathrm{mg} / \mathrm{l}$. At a df of 8 and a p-value of 0.592 , there was no significant difference between the TDS values obtained for the sachet and bottled water samples. However, TDS of all the water samples was observed to be within the WHO and NSDWQ standards of $1000 \mathrm{mg} / \mathrm{l}$ and $500 \mathrm{mg} / \mathrm{l}$ respectively. TDS above the WHO upper limit of $1000 \mathrm{mg} / \mathrm{l}$ affect the taste of drinking water negatively, making it unacceptable for drinking purpose. In the same vein, a very low level of TDS gives water a flat taste, this for many people is undesirable.

The salinity of the water samples was within the limit recommended for potable water. The Turbidity of drinking water is purely dependent on presence of particulate matter. Turbidity has effects on taste, odour and colour of water (Ndinwa et al., 2012). The turbidity of all the sachet and bottled water samples was less than $0.1 \mathrm{NTU}$. This is within the $0.2 \mathrm{NTU}$ recommended standard of WHO.

The temperature of sachet water samples ranged from $29.80-30.20^{\circ} \mathrm{C}$; the bottled water samples had a temperature range of $29.80-30.20^{\circ} \mathrm{C}$. At a df of 8 and a p-value of 0.626 , there was no significant difference between the temperature values obtained for the sachet and bottled water samples. Variation in temperature for packaged potable water is probably due to increased hours of exposure to sunlight during the day and improper storage of water. High temperature reduces the amount of dissolved oxygen in water, (Sawyer et al., 2000). The temperatures of the water samples were within the standard guidelines for drinking water.

Chloride ions concentration in the water samples varied from $6.00-47.99 \mathrm{mg} / \mathrm{l}$ for bottled water, with sample I having the highest concentration, while the range for sachet water was $6.00-24.85 \mathrm{mg} / \mathrm{l}$ as shown in Figure 2. At a df of 8 and a p-value of 0.649, there was no significant difference between the Chloride ion concentrations obtained for the sachet and bottled water samples. The values were however, within the WHO maximum permissible concentration of $250 \mathrm{mg} / 1$ desirable for drinking water. This limit is primarily based on taste considerations. However, intake of water containing higher concentrations of chloride, have not been widely reported to have adverse health effect on humans (Ndinwa et al., 2012). Higher levels of chloride ions in drinking water can become very 
evident in the taste of water. The values observed in this study were higher than $0.31-3.03 \mathrm{mg} / \mathrm{l}$ reported for sachet water analysis in Warri and Abraka, Nigeria (Ndinwa et al., 2012).

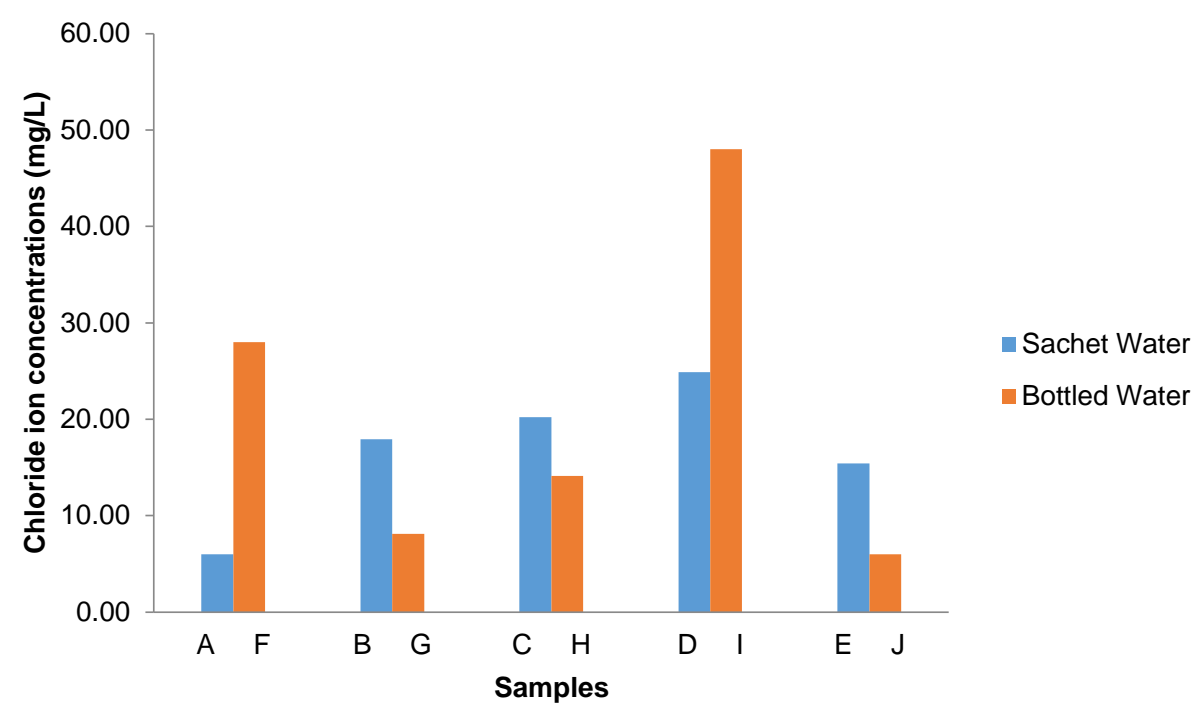

Figure 2: Chloride ion concentrations in the water samples

The range of nitrate ion levels in the water samples was $0.07-0.21 \mathrm{mg} / \mathrm{l}$ for sachet water and 0.08 $0.15 \mathrm{mg} / \mathrm{l}$ for bottled water. At a df of 8 and a p-value of 0.893 , there was no significant difference between the nitrate ion levels obtained for the sachet and bottled water samples. The results showed nitrate content to be relatively lower than the WHO and NSDWQ permissible limit of $50 \mathrm{mg} / \mathrm{l}$. Excessive amounts of nitrate ions can cause water quality problems, as well as contribute to the illness known as methemoglobinemia in infants (Zhang, 2007).

The concentration of nitrite ions in sachet water ranged from less than 0.001 to $0.08 \mathrm{mg} / \mathrm{l}$. The concentration is in compliance with the $3.0 \mathrm{mg} / \mathrm{l}$ maximum standard (WHO, 2017). The bottled water samples had a nitrite concentration range of less than 0.001 to $0.02 \mathrm{mg} / \mathrm{l}$. There was no significant difference in the nitrite ion levels for sachet and bottled water.

The distribution pattern of heavy metals concentrations in the study as observed on Table 3 is: $\mathrm{Fe}>\mathrm{Zn}>\mathrm{Mn}>\mathrm{Cu}>\mathrm{Pb}>\mathrm{Ar}$ for sachet water and $\mathrm{Fe}>\mathrm{Zn}>\mathrm{Cu}>\mathrm{Mn}>\mathrm{Pb}>\mathrm{Ar}$ for bottled water respectively. Copper occur naturally in water in only minute quantity (few micrograms per litre) in drinking water (Saleh et al., 2001). In all the water samples investigated, only three sample A (sachet water) with samples $\mathrm{F}$ and $\mathrm{H}$ (bottled water) contained this trace element at concentrations $0.05,0.05$ and $0.03 \mathrm{mg} / \mathrm{l}$ respectively. Copper was not detected in $70 \%$ of the samples. They were all within the $2.0 \mathrm{mg} / \mathrm{l}$ standard for drinking water (WHO, 2017). Higher level of copper is not desirable in drinking water as it could causes gastrointestinal disorder (SON, 2007).

Lead and Arsenic were not detected in all the samples. Iron as a trace element was not detected in about $40 \%$ of the water samples. Iron concentrations of 0.20 and $0.47 \mathrm{mg} / 1$ were observed in sachet water samples A and E. In four brands of bottled water samples $(G, H, I$ and J) iron levels ranged from $0.01-0.37 \mathrm{mg} / \mathrm{l}$. These observed values fall within the limit of $1.0 \mathrm{mg} / \mathrm{l}$ stipulated by World Health Organization (WHO, 2017) for drinking water. However, the levels of iron in samples F and J were slightly above the guideline set by NSDWQ.

Manganese concentration of $0.03 \mathrm{mg} / \mathrm{l}$ was detected in one sachet water sample, while concentrations of 0.10 and $0.08 \mathrm{mg} / \mathrm{l}$ respectively were observed in two bottled water samples ( $\mathrm{H}$ and I). These values are within the baseline values of 0.40 and $0.20 \mathrm{mg} / \mathrm{l}$ respectively set by WHO and NSDWQ respectively. Large quantities of manganese have an effect on water taste and enhance the growth of bacteria. Large doses of manganese have also been reported to cause lethargy, irritability, headache, sleeplessness, and leg weakness, which might induce psychological symptoms like violent behavior, inexplicable laughter, impulsive acts and absent-mindedness (Saleh et al., 2001). 
Zinc was detected in all the water samples. Its concentration ranged from $0.09-0.14 \mathrm{mg} / 1$ and $0.06-$ $0.15 \mathrm{mg} / \mathrm{l}$ for sachet and bottled water respectively as shown on Figure 3. At a df of 8 and a p-value of 0.916 , there was no significant difference between the zinc concentration values obtained for the sachet and bottled water samples. The values obtained were within the permissible level of $5.0 \mathrm{mg} / \mathrm{l}$ and $3.0 \mathrm{mg} / 1$ recommended by WHO and NSDWQ respectively.

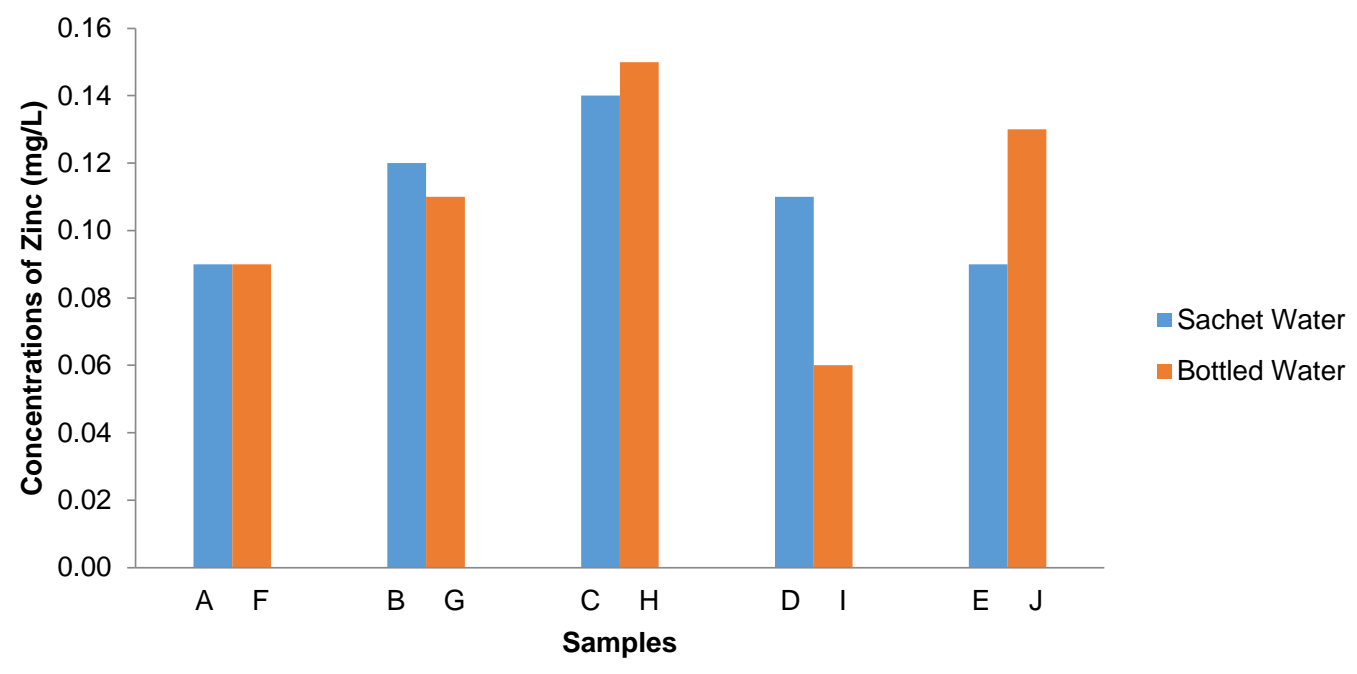

Figure 3: Zinc ion concentrations in the water samples

\subsection{Conclusions}

Sachet and bottled water play important roles in providing readily accessible water to the general populace; however, the quality of such water must be of paramount interest to all: producers, consumers and regulatory authorities alike. Samples of sachet and bottled water were collected from various retail outlets in Abraka and subjected to different analytical procedures to determine values of a range of physicochemical properties. The findings of this study revealed that the $\mathrm{pH}$ of $70 \%$ of the sachet and bottled water samples investigated was below permissible limits. The values of other parameters in the study such as: turbidity, colour, temperature, total dissolved solids, total hardness, electrical conductivity, chloride ion, nitrate ion, nitrite ion, and heavy metals such as copper, iron, zinc, and manganese were within the national and international guidelines. On the average, the sachet and bottled water samples were of good quality.

\section{References}

Adamu, S. (2009). Tackling Water Shortage in Kaduna. The Herald, Daily, Jan. 2, 2009, P. 5.

Adekunle, L. V., Sridhar, M. K. C., Ajayi, A. A., Oluwade, P. A. and Olawuyi, J. F. (2004). An Assessment of The Health and Social Economic Implications of Sachet Water in Ibadan Nigeria: A Public Health Challenge. African Journal of Biomedical Research 7, pp. 5-8.

Aderibigbe, S. A., Awoyemi, A. O. and Osagbemi, G. K. (2008). Availability, Adequacy and Quality of Water Supply in Ilorin Metropolis, Nigeria. European Journal of Scientific Research, 23(4), pp. 528-536.

Akinde, S. B., Nwachukwu, M. I. and Ogamba, A. S. (2011). Storage effects on the quality of sachet water produced within Port Harcourt metropolis, Nigeria. Journal of Biological Sciences 4, pp. 157164.

Akpoborie, I. A. and Ehwarimo, A. (2012). Quality of packaged drinking water produced in Warri Metropolis and potential implications for public health. Journal of Environmental Chemistry and Ecotoxicology, 4(11), pp.195-202. 
Akunyili, D. N. (2003). The Role of Pure Water and Bottled Water Manufacturers in Nigeria. Paper presented at the 29th Water, Engineering and Development Centre International Conference, in Abuja, Nigeria.

APHA, (2017). American Public Health Association, American Water works Association, Water Environment Federation, Standard Methods for the Examination of Water and Wastewater" $23^{\text {rd }}$ Edition., Washington, DC.

Aroh, K. N., Eze, E., Ukaji, D., Wachuku, C., Gobo, A. E., Abbe, S. D., et al. (2013). Health and environmental components of sachet water consumption and trade in Aba and Port Harcourt, Nigeria. Journal of Chemical Engineering and Materials Science, 4(2), pp. 13-22.

Dinrifo, R. R., Babatunde, S. O. E., Bankole, Y. O. and Demu, Q. A. (2010). Physico-Chemical Properties of Rain Water Collected from Some Industrial Areas of Lagos State Nigeria. European Journal of Scientific Research, 41(3), pp. 383-390.

Ezeugwunne, I. P., Agbakoba, N. R., Nnamah, N. K. and Anahalu, I. C. (2009). The prevalence of bacteria in packaged sachets water sold in Nnewi, South East, Nigeria. World Journal of Dairy \& Food Sciences, 4(1), pp.19-21.

Gangil, R., Tripathi, R., Patyal, A. and Dutta, P. (2013) Bacteriological Evaluation of Packaged Bottled Water sold at Jaipur city and its Public Health Significance. Vet World 6(1), pp. 27-30. doi:10.5455/vetworld.2013.27-30

Gbadegesin, N. and Olorunfemi, F. (2007). Assessment of Rural Water Supply Management in Selected Rural Areas of Oyo State. ATPS Working Paper, Series No. 49.

Guler, C. and Alpalsan, M. (2009). Mineral content of 70 bottled water brands sold on the Turkish market: Assessment of their compliance with current regulations, Journal of Food Composition and Analysis, 22, pp. 728-737

Isikwue, M. O. and Chikezie, A. (2014). Quality assessment of various sachet water brands marketed in Bauchi metropolis of Nigeria. International Journal of Advances in Engineering and Technology, 6, pp. 2489-2495.

Maconachie, R. (2008). Surface Water Quality and Periurban Food Production in Kano, Nigeria. Urban Agriculture Magazine, No. 20

Maduka, H. C. C., Chukwu, N. C., Ugwu, C. E., Dike, C. C., Okpogba, A. N., Ogueche, P. N. and Maduka, A. A. (2014).Assessment of commercial bottled table and sachet water commonly consumed in Federal University of Technology, Owerri (FUTO), Imo State, Nigeria using Microbiological indices. Journal of Dental and Medical Sciences, 13, pp. 86-89.

Ndinwa, C. C. G., Chukumah, O. C., Edafe, E. A., Obarakpor, K. I., Morka, W. and Osubor-Ndinwa, P. N. (2012).Physiochemical and Bacteriological Characteristics of Bottled and Sachet Water in Warri and Abraka, Southern Nigeria. Journal of Environmental Management and Safety, 3(2), pp. 145-160.

Nwidu, L. L., Oveh, B., Okoriye, T. and Vaikosen, N. A. (2008). Assessment of the water quality and prevalence of water borne diseases in Amassoma, Niger Delta, Nigeria. African Journal of Biotechnology, 7(17), pp. 2993-2997.

Omalu, I. C. J., Eze, G. C., Olayemi, I. K., Gbesi, S., Adeniran, L. A., Ayanwale, A.V., Mohammed, A. Z. and Chukwuemeka, V. (2011). Contamination of sachet water in Nigeria: Assessment and health impact. Online Journal of Health Allied Sciences, 9(4), p15.

Onifade, A. K. and Ilori, R. M. (2008). Microbiological analysis of sachet water vended in Ondo State, Nigeria. Environmental Research Journal, 2(3), pp. 107-110. 
Oyelude, E. O. and Ahenkorah, S. (2012). Quality of Sachet Water and Bottled Water in Bolgatanga Municipality of Ghana. Research Journal of Applied Sciences, Engineering and Technology, 4(9), pp. 1094-1098.

Saleh, M. A., Ewane, E., Jones, J. and Wilson, B. L. (2001). Chemical Evaluation of Commercial Bottled Drinking Water from Egypt. Journal of Food Composition and Analysis, 14(2), pp. 127-152.

Standards Organization of Nigeria SON (2007) Nigerian Standard for Drinking Water Quality. Abuja, Nigeria: SON Publishing Company, pp.15-33.

Thliza, L. A., Khan, A. U., Dangora, D. B. and Yahaya, A. (2015). Study of some bacterial load of some brands of sachet water sold in Ahmadu Bello University (Main Campus), Zaria, Nigeria. International Journal Current Science, 14, pp. 91-97.

Wetzel, R. G. (2001). Limnology; lake and River Ecosystem 3rd ed. Academic Press New York 1006 pp.

World Health Organisation WHO (2017), Guideline for Drinking Water Quality, 4th Edition. World Health Organisation, Geneva, Switzerland.

Zhang, J. (2007). Increasing Antarctic Sea Ice under Warming Atmospheric and Oceanic Conditions. Journal of Climate, 20, pp. 2515-2529. 